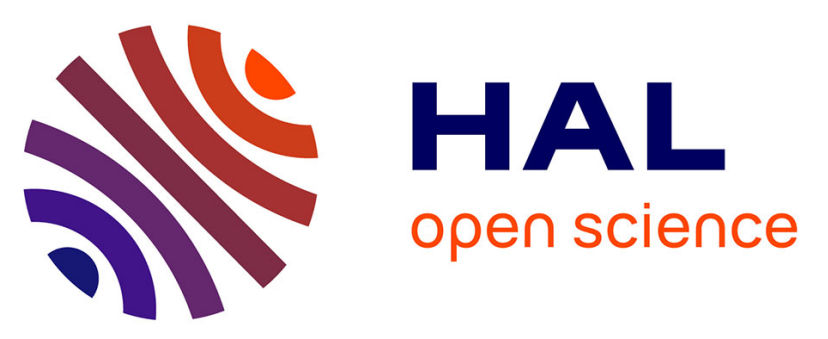

\title{
The effect of constitutive inactivation of the myostatin gene on the gain in muscle strength during postnatal growth in two murine models
}

Amalia Stantzou, Vanessa Ueberschlag-Pitiot, Rémi Thomasson, Denis Furling, Anne Bonnieu, Helge Amthor, Arnaud Ferry

\section{To cite this version:}

Amalia Stantzou, Vanessa Ueberschlag-Pitiot, Rémi Thomasson, Denis Furling, Anne Bonnieu, et al.. The effect of constitutive inactivation of the myostatin gene on the gain in muscle strength during postnatal growth in two murine models. Muscle \& Nerve, 2016, 55 (2), pp.254-261. 10.1002/mus.25220 . hal-01346093

\section{HAL Id: hal-01346093 \\ https: / hal.sorbonne-universite.fr/hal-01346093}

Submitted on 18 Jul 2016

HAL is a multi-disciplinary open access archive for the deposit and dissemination of scientific research documents, whether they are published or not. The documents may come from teaching and research institutions in France or abroad, or from public or private research centers.
L'archive ouverte pluridisciplinaire HAL, est destinée au dépôt et à la diffusion de documents scientifiques de niveau recherche, publiés ou non, émanant des établissements d'enseignement et de recherche français ou étrangers, des laboratoires publics ou privés. 
The effect of constitutive inactivation of the myostatin gene on the gain in muscle strength during postnatal growth in two murine models

Amalia Stantzou $\mathrm{PhD}^{1}$, Vanessa Ueberschlag-Pitiot $\mathrm{PhD}^{2}$, Remi Thomasson $\mathrm{PhD}^{3}$, Denis Furling $\mathrm{PhD}^{4}$, Anne Bonnieu $\mathrm{PhD}^{5}$, Helge Amthor $\mathrm{PhD}^{1}$, Arnaud Ferry $\mathrm{PhD}{ }^{4,6}$

1- Université de Versailles Saint-Quentin, Unité de formation et de recherche des sciences de la santé des sciences, Inserm U1179, LIA BAHN CSM Montigny-le-Bretonneux, France.

2- Université de Strasbourg, Institut de Génétique et de Biologie Moléculaire et Cellulaire, CNRS UMR7104/INSERM U964, Illkirch Cedex, France

3-Université Paris Descartes, Institut de Recherche bio-Médicale et d'Epidémiologie du Sport, Sorbonne Paris Cité, Paris, France.

4-Sorbonne Universités UPMC Univ Paris 06, Inserm, CNRS, Centre de Recherche en Myologie, Paris, France

5- INRA, Université Montpellier, UMR 866 Dynamique Musculaire et Métabolisme, Montpellier, France

6-Université Paris Descartes, Sorbonne Paris Cité, Paris, France.

\section{Maximal force without myostatin}

Correspondance :

A. Ferry

G.H. Pitié-Salpétrière, 47, bld de l'Hôpital, Bâtiment Babinski, Centre de recherche en myologie , 75651 Paris cedex 13, France.

arnaud.ferry@upmc.fr 


\begin{abstract}
Introduction. The effect of constitutive inactivation of the gene encoding myostatin on the gain in muscle performance during postnatal growth hsa not been well characterized. Methods. We analyzed 2 murine myostatin knockout (KO) models: i) the Lee model (KO $\left.{ }^{\text {Lee }}\right)$ and ii) the Grobet model $\left(\mathrm{KO}^{\text {Grobet }}\right)$, and measured the contraction of tibialis anterior muscle in situ. Results. Absolute maximal isometric force was increased in 6-month old $\mathrm{KO}^{\mathrm{Lee}}$ and $\mathrm{KO}^{\text {Grobet }}$ mice, as compared to wild-type mice. Similarly, absolute maximal power was increased in 6-month old $\mathrm{KO}^{\mathrm{Lee}}$ mice. In contrast, specific maximal force (relative maximal force per unit of muscle mass was decreased in all 6-month old male and female KO mice, except in 6-month old female $\mathrm{KO}^{\text {Grobet }}$ mice, whereas specific maximal power was reduced only in male $\mathrm{KO}^{\mathrm{Lee}}$ mice. Discussion. Genetic inactivation of myostatin increases maximal force and power, but in return it reduces muscle quality, particularly in male mice.
\end{abstract}

\title{
Keywords
}

Skeletal muscle; postnatal growth; knockout; myostatin; force; power; castration; orchidectomy 


\section{Introduction}

Myostatin, a member of the transforming growth factor beta family of signaling molecules, is a negative regulator of skeletal muscle growth. The gene encoding myostatin (Mstn) is expressed in both developing and adult muscle $(1 ; 2)$. In 2 mouse models and 1 rat model of constitutive Mstn knockout (KO), it has been reported that skeletal muscle undergoes marked hypertrophy (2-4). The supplementary Table S1 (available online) highights the increase in muscle weight, an index of muscle hypertrophy, that results mainly from hyperplasia in $\mathrm{KO}$ adult rodents $(2 ; 4-6)$. Many studies have examined muscle strength, i.e. absolute maximal force (tetanic isometric force), in $\mathrm{KO}$ adult rodents. The findings are extremely variable, since absolute maximal force has been reported to be increased $(4 ; 6 ; 7)$, unchanged (8-10), or even reduced (11) as compared to wild-type rodents. As shown in supplementary Table S1, the discrepancy in absolute maximal force appears to be more related to differences in the reduction of specific maximal force, i.e. absolute maximal force relative to muscle size, than to an increase in muscle weight (hypertrophy). Alternatively, the discrepancies between the studies may be due to methodological differences in force measurements (in situ versus in vitro, or nerve versus muscle stimulation), or to differences in ages, sexes, and genetic models.

The general aim of this study was to systematically determine the effect of constitutive genetic inactivation of myostatin on muscle performance gain during postnatal growth by analyzing different stages of postnatal development. We first analyzed absolute maximal force and absolute maximal power in 4 week-, 6 week-, 3 month-, and 6 month-old KO mice, using the mouse model generated by the Lee group to constitutively inactivate Mstn (2) (referred to hereafter as $\mathrm{KO}^{\mathrm{Lee}}$ mice). It is not yet known at what age the performance gain induced by Mstn inactivation occurs. We also evaluated whether the effect of genetic 
inactivation of myostatin varies between murine models. To this end, mice from the Grobet model of constitutive Mstn inactivation (3) (referred to hereafter as $\mathrm{KO}^{\text {Grobet }}$ mice) were studied and compared to $\mathrm{KO}^{\mathrm{Lee}}$ mice. Moreover, we analyzed the effect of castration in order to determine the effect of Mstn inactivation in the absence of sex hormones, which are additional potential regulators of muscle performance. In this study, mice of both sexes were studied since there have been reports of differences between sexes regarding the effect of Mstn inactivation on muscle performance $(7 ; 9)$.

\section{Materials and Methods}

Animals

All procedures were performed in accordance with national and European laws and were approved by your institutional animal care and use committee. Mice were group-housed in plastic cages and maintained on a standard chow-diet with a $12 \mathrm{~h}$ light and dark cycle, with $21^{\circ} \mathrm{C}$ room temperature.Two mouse models with constitutive Mstn inactivation were analyzed. We studied 61 female and 48 male $\mathrm{KO}^{\text {Lee }}$ mice, which were compared to 45 female and 61 male wild-type (WT) mice. $\mathrm{KO}^{\text {Lee }}$ mice founder breeding pairs were a gift from Se-Jin Lee (2). The $\mathrm{KO}^{\text {Lee }}$ mice carry a deletion of the entire mature C-terminal region (which comprises the third exon of the Mstn gene), which is replaced by a neo cassette. We used 10 female and 8 male $\mathrm{KO}^{\text {Grobet }}$ mice which were compared to 8 female and 7 male WT mice. We also studied some heterozygotous mice (HTZ ${ }^{\text {Lee }}$ mice). $\mathrm{KO}^{\text {Grobet }}$ mice founder breeding pairs were provided by Luc Grobet (3). The $\mathrm{KO}^{\text {Grobet }}$ mice carry the floxed Mstn allele (where the third exon of the Mstn gene is flanked with a pair of loxP sites) that was deleted at the zygote stage by a Cre plasmid. Both mouse models had a C57BL/6 
background. Some female and male $\mathrm{KO}^{\text {Lee }}$ mice ( $\mathrm{n}=24$ and $\mathrm{n}=19$ respectively), as well as female and male WT mice ( $n=14$ and $n=15$ respectively) were castrated (surgical removal of gonads) before age 4 weeks, approximately corresponding to the beginning of puberty (12). At age 6 months, body weights were $35.5 \pm 0.2 \mathrm{~g}$ (castrated $32.9 \pm 0.3 \mathrm{~g}$ ) in male $\mathrm{KO}^{\text {Lee }}$ mice, $30.0 \pm 0.5 \mathrm{~g}$ (castrated $30.9 \pm 1.1 \mathrm{~g}$ ) in male wildt-type (WT) mice, $29.8 \pm 0.4 \mathrm{~g}$ (castrated 30.0 $\pm 0.6 \mathrm{~g}$ ) in female $\mathrm{KO}^{\mathrm{Lee}}$ mice, $25.4 \pm 0.4 \mathrm{~g}$ (castrated $30.4 \pm 1.1 \mathrm{~g}$ ) in WT female mice.

\section{Muscle performance}

Force and power were evaluated by measuring in situ tibialis anterior (TA) muscle contraction in response to nerve stimulation, as described previously $(13 ; 14)$. Mice were anesthetized using pentobarbital $(60 \mathrm{mg} / \mathrm{kg}$ injected intraperitoneally). Body temperature was maintained at $37^{\circ} \mathrm{C}$ using radiant heat. The knee and foot were fixed with pins and clamps, and the distal tendon of the muscle was attached to a lever arm of a servomotor system (305B, Dual-Mode Lever, Aurora Scientific) using a silk ligature. The sciatic nerve was crushed proximally and stimulated distally by a bipolar silver electrode using $0.1 \mathrm{~ms}$ duration supramaximal square wave pulses. We measured the absolute maximal force (P0) that was generated during isometric contractions in response to electrical stimulation (frequency, $75-150 \mathrm{~Hz}, 500 \mathrm{~ms}$ stimulus train). Absolute maximal force was determined at L0 (length at which maximal tension was obtained during the tetanus). Absolute maximal force was normalized to the muscle mass as an estimate of specific maximal force (sP0), i.e. relative force-generating capacity per unit of muscle mass.

Force-velocity data were then obtained by eliciting contractions in response to sciatic nerve stimulation (500 ms, $125 \mathrm{~Hz}$ ) at 6 different afterloads over the range of approximately 10- 
$50 \%$ absolute maximal force. The sciatic nerve was stimulated for $700 \mathrm{~ms}(125 \mathrm{~Hz})$. A maximal isometric contraction of the muscle was initiated during the first $200 \mathrm{~ms}$. Then, the muscle shortened during the last $300 \mathrm{~ms}$ against the load. Each contraction was separated by a 1 min resting period. The (peak) shortening velocity was measured during the first $20 \mathrm{~ms}$ of the shortening period. The absolute power was calculated from the force-velocity data, and the absolute maximal power was reported (Pmax). Specific maximal power (sPmax) was calculated by dividing maximal power by muscle weight. After contractile measurements, the animals were sacrificed by cervical dislocation, and muscles were removed and weighed.

Statistical analysis

Groups were generally compared using 2-way analysis of variance (genotype $\mathrm{x}$ age, sex $\mathrm{x}$ age, sex $\mathrm{x}$ genotype, castration $\mathrm{x}$ age) of variance. If necessary, Bonferroni post-tests were also performed. For groups that did not pass tests of normality and equal variance, nonparametric tests were used (Kruskal Wallis and Wilcoxon). Values are reported as mean \pm standard error of the mean (SEM). Significance was set at $P<0.05$.

\section{Results}

Effect of Mstn inactivation: Lee model

There were significant $(P<0.05)$ effects of both age and genotype on absolute maximal force and interaction between factors in male $\mathrm{KO}^{\text {Lee }}$ mice. The analyses revealed that absolute maximal force increased with age $(P<0.05)$ and peaked at ages 3 and 6 months in 
male $\mathrm{KO}^{\text {Lee }}$ mice and at age 6 months in male WT mice (Figure 1A). Moreover, absolute maximal force was increased in 3-month old male $\mathrm{KO}^{\text {Lee }}$ mice $(+45 \%)$ and 6-month old male $\mathrm{KO}^{\text {Lee }}$ mice $(+41 \%)$, as compared to age-matched male WT mice (Figure 1A). However, absolute maximal force was decreased in 6-week old male $\mathrm{KO}^{\text {Lee }}$ mice compared to WT (Figure 1A). In contrast to male $\mathrm{KO}^{\text {Lee }}$ mice, absolute maximal force was only increased in 6-month old female $\mathrm{KO}^{\text {Lee }}$ mice $(+55 \%)$, but not at age 3 months, as compared to age-matched female WT mice (Figure 1B). Gender dimorphism was also studied by a 2way analysis of variance (gender $\mathrm{x}$ age) in $\mathrm{KO}^{\mathrm{Lee}}$ and WT mice. The analyses revealed that, in contrast to WT mice, only the absolute maximal force of 3-month old male $\mathrm{KO}^{\mathrm{Lee}}$ mice (Figure 1A) was increased compared to age-matched female $\mathrm{KO}^{\text {Lee }}$ mice (Figure 1B).

Specific maximal force (absolute maximal force/muscle weight) was decreased in 4-week, 6-week, 3- (-23\%), and 6-month old (-34\%) male $\mathrm{KO}^{\text {Lee }}$ mice, as compared to age-matched male WT mice (Figure 1C). Similarly, specific maximal force was reduced in female $\mathrm{KO}^{\text {Lee }}$ mice at ages 6 weeks, 3 months (-30\%), and 6 months (-20\%), as compared to age-matched female WT mice (Figure 1D). Moreover, in contrast to WT mice, the specific maximal force of male $\mathrm{KO}^{\text {Lee }}$ mice (Figure $1 \mathrm{C}$ ) was reduced as compared to age-matched female $\mathrm{KO}^{\text {Lee }}$ mice (Figure 1D).

Another important aspect of muscle performance is the absolute maximal power, a more dynamic measure that also accounts for shortening velocity. Absolute maximal power increased with age $(P<0.05)$ and peaked at ages 3 and 6 months in male $\mathrm{KO}^{\mathrm{Lee}}$ and WT mice. Three-month $(+61 \%)$ and 6-month $(+72 \%)$ old male $\mathrm{KO}^{\text {Lee }}$ mice had a greater absolute maximal power than age-matched male WT mice (Figure 2A). In contrast to male $\mathrm{KO}^{\text {Lee }}$ mice, absolute maximal power was only increased in 6-month old female $\mathrm{KO}^{\text {Lee }}$ mice 
(+97\%), but not in 3-month-old female $\mathrm{KO}^{\mathrm{Lee}}$ mice, as compared to age-matched female WT mice (Figure 2B). Moreover, in contrast to WT mice, only the absolute maximal power of 3month old male $\mathrm{KO}^{\text {Lee }}$ mice (Figure $2 \mathrm{~A}$ ) was increased as compared to age-matched female $\mathrm{KO}^{\text {Lee }}$ mice (Figure 2B).

Absolute maximal power was related to specific maximal power and muscle weight (see below). Specific maximal power was reduced in 4-week, 3-, and 6-month old (-22\%) male $\mathrm{KO}^{\mathrm{Lee}}$ mice, as compared to age-matched male WT mice (Figure 2C). In contrast to male $\mathrm{KO}^{\mathrm{Lee}}$ mice, specific maximal power was not reduced in female $\mathrm{KO}^{\text {Lee }}$ mice, as compared to age-matched female WT mice (Figure 2D). Moreover, in contrast to WT mice, the specific maximal power of male $\mathrm{KO}^{\text {Lee }}$ mice was not increased (Figure $2 \mathrm{C}$ ), as compared to agematched female $\mathrm{KO}^{\text {Lee }}$ mice (Figure 2D).

We also analyzed muscle weight, because force and power are proportional to muscle size (muscle cross-section area and volume). Muscle weights increased with age $(P<0.05)$ and peaked at ages 3 and 6 months in both male $\mathrm{KO}^{\mathrm{Lee}}$ and WT mice. The muscle weight of 3and 6-month old male $\mathrm{KO}^{\text {Lee }}$ mice was greater $(+83 \%$ and $+114 \%)$, as compared to agematched male WT mice (Figure 3A). Similarly to male $\mathrm{KO}^{\text {Lee }}$ mice, muscle weight was increased in female $\mathrm{KO}^{\text {Lee }}$ mice at ages 3 and 6 months (+67\% and $+96 \%$ ), as compared to age-matched female WT mice (Figure 3B). However, in contrast to male $\mathrm{KO}^{\text {Lee }}$ mice, muscle weight was also increased in female $\mathrm{KO}^{\text {Lee }}$ mice at age 4 weeks, as compared to agematched female WT mice (Figure 3B). Moreover, similarly to WT mice, the muscle weight of 3- and 6-month old male $\mathrm{KO}^{\mathrm{Lee}}$ mice was greater (Figure 3A), as compared to agematched female $\mathrm{KO}^{\text {Lee }}$ mice (Figure 3B). 
We also studied the effect of inactivation of a single copy of the Mstn allele in heterozygous (referred to as $\mathrm{HTZ}^{\mathrm{Lee}}$ ) mice in the Lee model at age 3 months. Similarly to 3-month old male $\mathrm{KO}^{\mathrm{Lee}}$ mice, absolute maximal force was increased in 3-month old male $\mathrm{HTZ}^{\mathrm{Lee}}$ mice, as compared to age-matched male WT mice (Figure $4 \mathrm{~A}$ ). In contrast to 3-month old $\mathrm{KO}^{\text {Lee }}$ mice, specific maximal force was not reduced in 3-month old male and female HTZ ${ }^{\text {Lee }}$ mice, as compared to age- and sex-matched WT mice (Figure 4A,B). In contrast to 3-month old $\mathrm{KO}^{\text {Lee }}$ mice, muscle weight was less or not increased in 3-month old male and female $\mathrm{HTZ}^{\text {Lee }}$ mice, respectively, as compared to age- and sex-matched WT mice (Figure 4A,B). Together, these results suggest a dose-dependent effect of Mstn inactivation.

Effect of Mstn inactivation in castrated mice (Lee model)

Mice were castrated at age 4 weeks in both male and female $\mathrm{KO}^{\text {Lee }}$ mice, and they were studied at ages 3 and 6 months. In contrast to intact male $\mathrm{KO}^{\text {Lee }}$ mice (not castrated) (Figure $1 \mathrm{~A})$, absolute maximal force was increased $(+63 \%)$ in 3 -month old castrated male $\mathrm{KO}^{\text {Lee }}$ mice but not at age 6 months, as compared to age-matched castrated male WT mice (Figure 5A). Similarly to intact male $\mathrm{KO}^{\mathrm{Lee}}$ mice (Figures $2 \mathrm{~A}$ and $3 \mathrm{~A}$ ), absolute maximal power and muscle weight were increased in 3- and 6-month old castrated male $\mathrm{KO}^{\text {Lee }}$ mice $(+100 \%$, $+91 \%$ respectively), as compared to age-matched castrated WT mice (Figures 5BC).

In contrast to intact female $\mathrm{KO}^{\text {Lee }}$ mice (Figures $1 \mathrm{~B}$ and $2 \mathrm{~B}$ ), absolute maximal force and absolute maximal power were increased in both 3-and 6-month old castrated female $\mathrm{KO}^{\text {Lee }}$ mice, as compared to age-matched castrated female WT mice (Figure 5DE). Similarly to 
intact female $\mathrm{KO}^{\text {Lee }}$ mice (Figures 3B), muscle weight was increased in 3- and 6-month old castrated female $\mathrm{KO}^{\mathrm{Lee}}$ mice, as compared to age-matched castrated WT mice (Figure 5F).

Taken together, these results suggest that castration modulates some effects of Mstn inactivation.

Effect of Mstn inactivation: Grobet Model

Two-way analyses of variance (genotype $\mathrm{x}$ gender; genotype $\mathrm{x}$ age) were performed. The latter revealed that absolute maximal force was increased in 6-month old male and female $\mathrm{KO}^{\text {Grobet }}$ mice, as compared to sex-and age-matched WT mice (Figure 6A). In contrast to male $\mathrm{KO}^{\text {Grobet }}$ mice $(+16 \%)$, absolute maximal force increased more markedly in 6-month old female $\mathrm{KO}^{\text {Grobet }}$ mice $(+65 \%)$, as compared to age-matched female WT mice (Figure 6A). Absolute maximal force was also increased in 6 week-old female $\mathrm{KO}^{\text {Grobet }}$ mice (Figure 6A). Moreover, in contrast to WT mice, the absolute maximal force was not increased in 6month old male $\mathrm{KO}^{\text {Grobet }}$ mice, as compared to age-matched female $\mathrm{KO}^{\text {Grobet }}$ mice (Figure $6 \mathrm{~A})$.

Specific maximal force was decreased in 6-month old male $\mathrm{KO}^{\text {Grobet }}$ mice $(-35 \%)$, as compared to age-matched male WT mice (Figure $6 \mathrm{~B}$ ). In contrast to male $\mathrm{KO}^{\text {Grobet }}$ mice, specific maximal force was not reduced in 6-month old female $\mathrm{KO}^{\text {Grobet }}$ mice, as compared to age-matched female WT mice (Figure 6B) $(P=0.055)$. However, specific maximal force was reduced in female $\mathrm{KO}^{\text {Grobet }}$ mice $(-33 \%)$ at age 6 weeks. There were no other signs of gender dimorphism. 
The muscle weight of 6-month old male and female $\mathrm{KO}^{\text {Grobet }}$ mice was greater by $+73 \%$ and $+87 \%$, respectively as compared to sex-and age-matched WT mice (Figure 6C). Moreover, muscle weight was also increased in 6-week old female $\mathrm{KO}^{\text {Grobet }}$ mice (Figure 6C). Furthermore, in both genotypes, the muscle weight of 6-month old male mice was greater as compared to age-matched female mice (Figure 6C).

We next compared the effect of Mstn inactivation between the Lee and Grobet models. Table 1 shows the effect of Mstn inactivation on muscle weight, absolute maximal force, and specific maximal force in $\mathrm{KO}^{\mathrm{Lee}}$ and $\mathrm{KO}^{\text {Grobet }}$ mice of both sexes at age 6 months. Absolute maximal force increased in both sexes and models $(P<0.05)$, but to a lower extent in male $\mathrm{KO}^{\text {Grobet }}$ mice. Specific maximal force decreased in both male and female $\mathrm{KO}^{\text {Lee }}$ mice and male $\mathrm{KO}^{\text {Grobet }}$ mice $(P<0.05)$, but not in female $\mathrm{KO}^{\text {Grobet }}$ mice. In both models, muscle weight increased in male and female KO mice $(\mathrm{p}<0.05)$. Together, these results indicate some differences between the 2 models.

\section{Discussion}

Mstn inactivation increases absolute maximal force/power in 6-month old mice

A main finding of our study is that inactivation of the Mstn gene increased absolute maximal force at age 6 months in both models and sexes, in line with some but not all previous studies (see supplementary table). However, the extent of the increase varied markedly $(+16 \%$ to $+65 \%)$, depending on the model and sex. Absolute maximal power was also increased in 6-month old $\mathrm{KO}$ mice, at least in $\mathrm{KO}^{\mathrm{Lee}}$ mice. However, the general notion that Mstn inactivation increases maximal force/power may be incorrect in younger $\mathrm{KO}^{\text {Lee }}$ mice 
since, for example, absolute maximal force was found unchanged in 3-month old female $\mathrm{KO}^{\text {Lee }}$ mice and was reduced in 6-week old male $\mathrm{KO}^{\text {Lee }}$ mice.

Interestingly, our study indicates that the increase in maximal force and power occurs late during postnatal growth in the Lee model (at ages 3 and 6 months). This is apparently not the case in the Grobet model, in which a notable absolute maximal force gain was observed in 6-week old female $\mathrm{KO}^{\text {Grobet }}$ mice. The explanation of this delayed effect in the Lee model can likely be explained by the fact that no substantial muscle hypertrophy (increased weight) occured until age 3 or 6 months in $\mathrm{KO}^{\mathrm{Lee}}$ mice, in contrast to the Grobet model. This result suggests that the effect of Mstn inactivation on muscle size in the Lee model only occurs during the postnatal growth stage in which fiber growth is achieved without myonuclear accretion (beyond age 3 weeks) (15).

\section{Mstn inactivation reduces specific maximal force}

We also found that Mstn inactivation reduces specific maximal force (-20 to $-35 \%)$, i.e. relative force generating capacity per unit of muscle mass (muscle quality), except in 6month old female $\mathrm{KO}^{\text {Grobet }}$ mice (see Table 1). These results are in line with several previous studies (see supplementary Table). The fact that specific maximal force was not reduced in 6-month old female $\mathrm{KO}^{\text {Grobet }}$ as compared to age-matched female WT mice $(\mathrm{p}=0.055)$ has to be confirmed since younger female $\mathrm{KO}^{\text {Grobet }}$ mice exhibited a reduction $(-33 \%)$ in specific maximal force. Moreover, we detected a Mstn gene dose effect, as inactivation of a single Mstn gene allele is not sufficient to lead to a decrease in the specific maximal force (no reduction in $\mathrm{HTZ}^{\mathrm{Lee}}$ mice). It is noteworthy that the reduced specific maximal force decreases the potential gain in absolute maximal force (see above) that can be expected on 
the basis of muscle hypertrophy in both models (see Table 1).

An interesting finding was that the lower specific maximal force occurs very early during postnatal growth (4 or 6 weeks). Another important result of this study is that the reduced specific maximal force is not related to muscle hypertrophy, since notable hypertrophy occurs later, at least in the Lee model (in 3-month old male and female $\mathrm{KO}^{\text {Lee }}$ mice).

Previous studies have shown that Mstn inactivation reduces specific maximal force produced by individual permeabilized muscle fibers when activated by external calcium $(16 ; 17)$. Moreover, a recent study reported a reduction in electrically evoked calcium release in mice with a mutation in Mstn probably due to reduction of calcium content in the sarcoplasmic reticulum (18). Therefore, one can postulate that the reduced specific maximal force in both models is likely caused by decreased myofibrillar function, and a dysfunction of sarcoplasmic calcium release. Since we found no reduced specific maximal force in 6-month old female $\mathrm{KO}^{\text {Grobet }}$, we hypothesise that in these mice there is no dysfunction. The lower muscle quality resulting from Mstn inactivation is also evidenced by reduced specific maximal power, at least in male $\mathrm{KO}^{\mathrm{Lee}}$ mice. Since it has been shown that exercise training can normalize specific maximal force in $\mathrm{KO}^{\text {Lee }}$ mice $(11)$, it is possible that the reduced muscle quality results from a lower amount of habitual activity. However, a recent study failed to demonstrate any reduction in the level of home cage voluntary locomotor activity in $\mathrm{KO}^{\mathrm{Lee}}$ mice (19). It is noteworthy that inactivation of myostatin has been shown to induce a fiber type shift (8). In future studies, it would be of interest to determine the effect of Mstn inactivation on the work loop power output, since the work loop technique relates well to the dynamic muscle performance in vivo (20). 
We found several differences between sexes at ages 3 and 6 months in $\mathrm{KO}$ mice of both models, i.e. in mature mice. First, the effect of Mstn inactivation varied between genders in both models. Notable increases in absolute maximal force and power occur later in female $\mathrm{KO}^{\mathrm{Lee}}$ mice as compared to male $\mathrm{KO}^{\mathrm{Lee}}$ mice. Moreover, in contrast to male $\mathrm{KO}^{\mathrm{Grobet}}$ mice, there was no reduction in specific maximal force, and absolute maximal force increased more in female $\mathrm{KO}^{\text {Grobet }}$ mice. Secondly, gender dimorphism decreased with Mstn inactivation in both models. In contrast to WT mice, there were no differences between sexes concerning absolute maximal force and absolute maximal power in both models. Sexual dimorphism concerning performance was reduced in $\mathrm{KO}$ mice, because absolute maximal force and power continued to increase beyond age 3 months in female $\mathrm{KO}^{\mathrm{Lee}}$ mice, and specific maximal force was not reduced in female $\mathrm{KO}^{\text {Grobet }}$ mice. These results confirmed that the effects of Mstn inactivation on absolute and specific maximal forces can vary between sexes $(7 ; 9)$.

Less is known concerning the interaction of Mstn and other regulators of muscle growth, such as sex hormones $(14 ; 21-23)$. Recent studies reported that Mstn is an androgen target in skeletal muscle (24-26). We found that castration decreased the effect of Mstn inactivation on absolute maximal force in 6-month old male $\mathrm{KO}^{\mathrm{Lee}}$ mice (there was no longer any difference between genotypes in castrated male mice). In contrast, castration increased the effect of Mstn inactivation on both absolute maximal force and power in 3-month old female $\mathrm{KO}^{\text {Lee }}$ mice (a difference appears between genotypes). Together, our findings suggest that removal of endogenous androgens and estrogens, respectively attenuates and promotes the effect of Mstn inactivation on some aspects of muscle performance. Thus, it would be of 
interest to explore the mechanisms of this potential interaction between Mstn and sex hormones.

\section{Conclusion}

This study demonstrates that constitutive Mstn inactivation increases absolute maximal force of 6-month old KO mice in both models and sexes. Similarly, absolute maximal power is increased by genetic deficiency of myostatin at 6 months of age in both sexes, at least in the Lee model. The gain in muscle performance largely varies between models and sexes, but not for methodological reasons. Moreover, this effect of Mstn inactivation might not be observed in younger $\mathrm{KO}$ mice, at least in the Lee model. In contrast, specific maximal force is reduced with Mstn inactivation and occurs earlier during postnatal growth, but the extent of the reduction also varies between models and sexes. In the Lee model, reduced specific maximal force was not related to the hypertrophic effect of Mstn inactivation, at least in younger mice. Moreover, Mstn inactivation reduced the sexual dimorphism regarding absolute maximal force in both models. We show that castration modulates the effect of Mstn inactivation, at least in the Lee model, confirming the notion that endogenous androgens and estrogens might attenuate and promote, respectively the effect of Mstn inactivation on some aspects of performance. Together, these results indicate that endogenous myostatin plays an important role during postnatal skeletal muscle development in mice. It limits the gains in absolute maximal force and power, but in return it improves muscle quality, notably with regard to high intensity muscle contractile function, particularly in male mice. However, the role of endogenous myostatin varies between models and sexes, for yet unknown physiological reasons, as we excluded methodological bias. 


\section{Acknowledgements}

We are grateful to Antoine Espagnol, Arthur Cetaire, Juliette Breuil and Saad IdrissiZouggari (Université Pierre et Marie Curie) for their assistance during the experiments and Daniel Owens for the carefully proofreading the text.

Financial support has been provided by Université Pierre et Marie Curie (UPMC), CNRS, INSERM, University Paris Descartes, the Association Française contre les Myopathies. We would like to acknowledge Deutsche Forschungsgemeinschaft and the Université FrancoAllemand towards A.S. and H.A. (as part of the MyoGrad International Graduate School for Myology DRK 1631/1 and CDFA-06-11), 


\section{Abbreviations}

$\mathrm{KO}$ : knockout, with genetic myostatin inactivation

$\mathrm{KO}^{\text {Grobet }}$ : mice with genetic myostatin inactivation from the model of Grobet laboratory

$\mathrm{KO}^{\text {Lee: }}$ mice with genetic myostatin inactivation from the level of Lee laboratory

Mstn : gene encoding myostatin

P0 : absolute maximal force

Pmax : absolute maximal power

sP0 : specific maximal force

sPmax : specific maximal power

TA : tibialis anterior muscle

WT : wild-type 


\section{References}

1. McMahon CD, Popovic L, Jeanplong F, Oldham JM, Kirk SP, et al. Sexual dimorphism is associated with decreased expression of processed myostatin in males. Am J Physiol Endocrinol Metab 2003;284(2):E377- 81.

2. McPherron AC, Lawler AM, Lee SJ. Regulation of skeletal muscle mass in mice by a new TGF-beta superfamily member. Nature 1997;387(6628):83- 90.

3. Grobet L, Pirottin D, Farnir F, Poncelet D, Royo LJ, Brouwers B, et al. Modulating skeletal muscle mass by postnatal, muscle-specific inactivation of the myostatin gene. Genesis 2003;35(4):227-38.

4. Mendias CL, Lynch EB, Gumucio JP, Flood MD, Rittman DS, Van Pelt DW, et al. Changes in skeletal muscle and tendon structure and function following genetic inactivation of myostatin in rats. J Physiol 2015;593(8):2037- 52.

5. Gay S, Jublanc E, Bonnieu A, Bacou F. Myostatin deficiency is associated with an increase in number of total axons and motor axons innervating mouse tibialis anterior muscle. Muscle Nerve 2012;45(5):698- 704.

6. Mendias CL, Marcin JE, Calerdon DR, Faulkner JA. Contractile properties of EDL and soleus muscles of myostatin-deficient mice. J Appl Physiol 2006;101(3):898- 905.

7. Schirwis E, Agbulut O, Vadrot N, Mouisel E, Hourde C, Bonnieu A, et al. The beneficial effect of myostatin deficiency on maximal muscle force and power is attenuated with age. Exp Gerontol 2013;48(2):183- 90.

8. Amthor H, Macharia R, Navarrete R, Schuelke M, Brown SC, Otto A, et al. Lack of myostatin results in excessive muscle growth but impaired force generation. Proc Natl Acad Sci U A 2007;104(6):1835- 40.

9. Gentry BA, Ferreira JA, Phillips CL, Brown M. Hindlimb skeletal muscle function in myostatin-deficient mice. Muscle Nerve 2011;43(1):49- 57.

10. Ploquin C, Chabi B, Fouret G, Vernus B, Feillet-Coudray C, Coudray C, et al. Lack of myostatin alters intermyofibrillar mitochondria activity, unbalances redox status, and impairs tolerance to chronic repetitive contractions in muscle. Am J Physiol Endocrinol Metab 2012;302(8):E1000- 8.

11. Matsakas A, Macharia R, Otto A, Elashry MI, Mouisel E, Romanello V, et al. Exercise training attenuates the hypermuscular phenotype and restores skeletal muscle function in the myostatin null mouse. Exp Physiol 2012;97(1):125- 40.

12. Pinter O, Beda Z, Csaba Z, Gerendai I. Differences in the onset of puberty in selected inbred mouse strains. Endocr. Abstr. 2007;14:617.

13. Ferry A, Parlakian A, Joanne P, Fraysse B, Mgrditchian T, Roy P, et al. Mechanical Overloading Increases Maximal Force and Reduces Fragility in Hind Limb Skeletal Muscle from Mdx Mouse. Am J Pathol 2015;185(7):2012- 24. 
14. Hourde C, Joanne P, Noirez P, Agbulut O, Butler-Browne G, Ferry A. Protective effect of female gender-related factors on muscle force-generating capacity and fragility in the dystrophic mdx mouse. Muscle Nerve 2013;48(1):68- 75.

15. White RB, Bierinx AS, Gnocchi VF, Zammit PS. Dynamics of muscle fibre growth during postnatal mouse development. BMC Dev Biol 2010;10:21.

16. Mendias CL, Kayupov E, Bradley JR, Brooks SV, Claflin DR. Decreased specific force and power production of muscle fibers from myostatin-deficient mice are associated with a suppression of protein degradation. J Appl Physiol 2011;111(1):185- 91.

17. Qaisar R, Renaud G, Morine K, Barton ER, Sweeney HL, Larsson L. Is functional hypertrophy and specific force coupled with the addition of myonuclei at the single muscle fiber level? Faseb J 2012;26(3):1077- 85.

18. Bodnar D, Geyer N, Ruzsnavszky O, Olah T, Hegyi B, Sztretye M, et al. Hypermuscular mice with mutation in the myostatin gene display altered calcium signalling. J Physiol 2014;592(Pt 6):1353- 65.

19. Mouisel E, Relizani K, Mille-Hamard L, Denis R, Hourdé C, Agbulut O, et al. Myostatin is a key mediator between energy metabolism and endurance capacity of skeletal muscle. Am. J. Physiol. Regul. Integr. Comp. Physiol. 2014 août;307(4):R444- 454.

20. James RS, Altringham JD, Goldspink DF. The mechanical properties of fast and slow skeletal muscles of the mouse in relation to their locomotory function. J. Exp. Biol. 1995 févr;198(Pt 2):491- 502.

21. Chambon C, Duteil D, Vignaud A, Ferry A, Messaddeq N, Malivindi R, et al. Myocytic androgen receptor controls the strength but not the mass of limb muscles. Proc Natl Acad Sci U A 2010;107(32):14327- 32.

22. Greising SM, Carey RS, Blackford JE, Dalton LE, Kosir AM, Lowe DA. Estradiol treatment, physical activity, and muscle function in ovarian-senescent mice. Exp Gerontol 2011;46(8):685- 93.

23. Hourde C, Jagerschmidt C, Clement-Lacroix P, Vignaud A, Ammann P, ButlerBrowne GS, et al. Androgen replacement therapy improves function in male rat muscles independently of hypertrophy and activation of the Akt/mTOR pathway. Acta Physiol. 2009;195(4):471- 82.

24. Braga M, Bhasin S, Jasuja R, Pervin S, Singh R. Testosterone inhibits transforming growth factor-beta signaling during myogenic differentiation and proliferation of mouse satellite cells: potential role of follistatin in mediating testosterone action. Mol Cell Endocrinol 2013;350(1):39- 52.

25. Dubois V, Laurent M, Boonen S, Vanderschueren D, Claessens F. Androgens and skeletal muscle: cellular and molecular action mechanisms underlying the anabolic actions. Cell Mol Life Sci 2013;69(10):1651- 67. 
26. Mendler L, Baka Z, Kovacs-Simon A, Dux L. Androgens negatively regulate myostatin expression in an androgen-dependent skeletal muscle. Biochem Biophys Res Commun 2007;361(1):237- 42. 
Legends of figures

Figure 1. Absolute and specific maximal forces of tibialis anterior muscles in male (AC) and female (BD) $\mathrm{KO}^{\mathrm{Lee}}$ mice. $\mathrm{A}$ and $\mathrm{B}$ : absolute maximal force $(\mathrm{P} 0) ; \mathrm{C}$ and $\mathrm{D}$ : specific maximal force $(\mathrm{sP0}) . \mathrm{a}: \mathrm{KO}$ different from corresponding WT $(P<0.05)$. $\mathrm{c}:$ male different from corresponding female $(P<0.05) . \mathrm{n}=8$-28/group for female mice and n=6-22/group for male mice

Figure 2. Absolute and specific maximal powers of tibialis anterior muscle in male $(A, C)$ and female $(\mathrm{B}, \mathrm{D}) \mathrm{KO}^{\text {Lee }}$ mice. $\mathrm{A}$ and $\mathrm{B}$ : absolute maximal power (Pmax) ; C and D : specific maximal power (sPmax). a : KO different from corresponding WT $(P<0.05)$.

$\mathrm{c}:$ male mice different from corresponding female mice $(P<0.05) . \mathrm{n}=6-14$ /group for female and $n=6-12 /$ group for male

Figure 3. Muscle weight of tibialis anterior muscle in male (A) and female (B) $\mathrm{KO}^{\text {Lee }}$ mice. a : KO different from corresponding WT $(P<0.05)$. $\mathrm{c}:$ male different from corresponding female $(P<0.05) . n=8-28 /$ group for female mice and n=6-22/group for male mice

Figure 4. Absolute and specific maximal forces, and weight of tibialis anterior muscle in male (A) and female (B) HTZ ${ }^{\text {Lee }}$ mice. HTZ : heterozygous mice ; P0 : absolute maximal force ; sP0 : specific maximal force. a : KO or HTZ different from corresponding WT $(P<$ 0.05). $\mathrm{d}$ : KO different from corresponding HTZ $(P<0.05) . \mathrm{n}=6-34 /$ group for female mice and $\mathrm{n}=6-28$ /group for male mice

Figure 5. Absolute maximal force and power, and weight of tibialis anterior muscle in 
castrated male (A-C) and female (D-F) $\mathrm{KO}^{\text {Lee }}$ mice. P0 : absolute maximal force ; sP0 : specific maximal force ; Pmax : absolute maximal power ; sPmax : specific maximal power. a : KO different from corresponding WT $(P<0.05)$. n=7-22/group for female mice and $n=8$ 28/group for male mice.

Figure 6. Absolute (A) and specific (B) maximal forces, and weight (C) of tibialis anterior muscle in male and female $\mathrm{KO}^{\text {Grobet }}$ mice. $\mathrm{P0}$ : absolute maximal force; $\mathrm{sP} 0$ : specific maximal force ; a : KO different from corresponding WT $(\underline{\mathrm{P}}<0.05)$; $\mathrm{c}:$ male different from corresponding female $(P<0.05)$; n=8-16/group for female mice and $\mathrm{n}=10-16 /$ group for male mice 
Table 1. Effect of Mstn inactivation in both Lee and Grobet mouse models at age 6 months.

$\begin{array}{llll}\mathrm{KO}^{\text {Lee }} & & \mathrm{KO}^{\text {Grobet }} & \\ \text { Male } & \text { Female } & \text { Male } & \text { Female }\end{array}$

$\begin{array}{lllll}\text { Absolute maximal force (P0) } & +41 \% & +55 \% & +16 \% & +65 \% \\ \text { Specific maximal force (sP0) } & -34 \% & -20 \% & -35 \% & = \\ \text { Muscle weight } & +114 \% & +96 \% & +75 \% & +87 \%\end{array}$

=: no significant difference; -: decrease; +: increase; $\mathrm{KO}^{\text {Grobet }}$ : mice with myostatin inactivation from the model of Grobet; $\mathrm{KO}^{\mathrm{Lee}}$ : mice with myostatin inactivation from the level of Lee. 
Figure 1

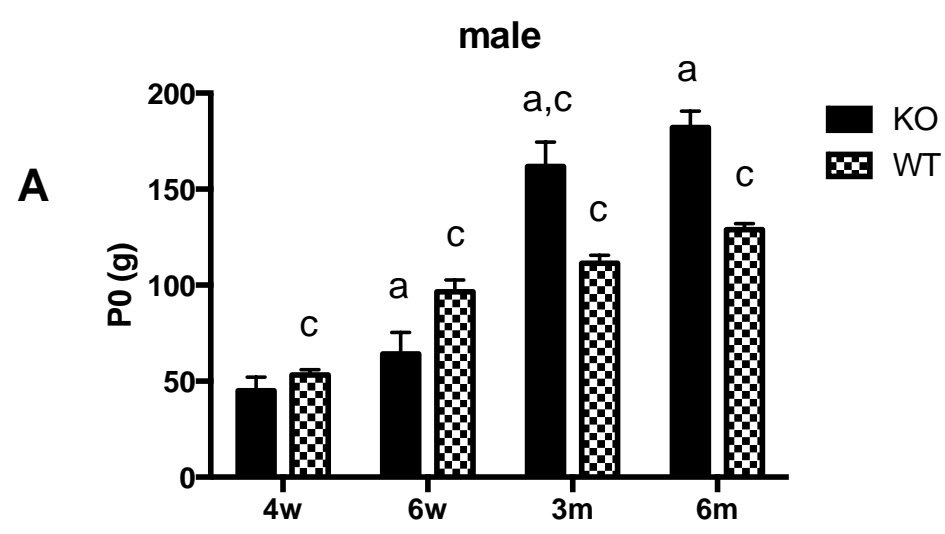

female

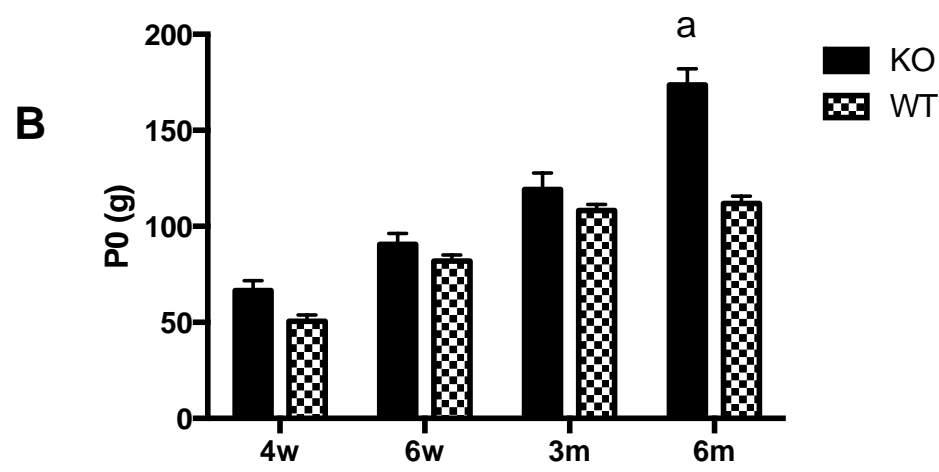

male

c

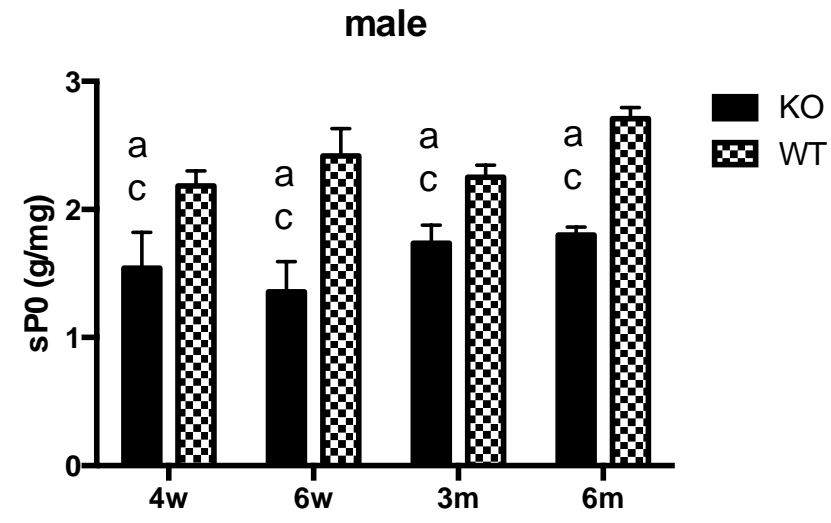

female

D

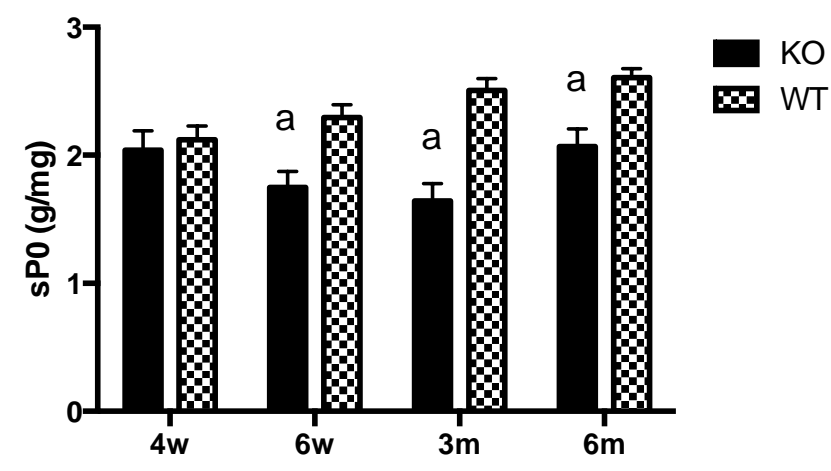


Figure 2

A

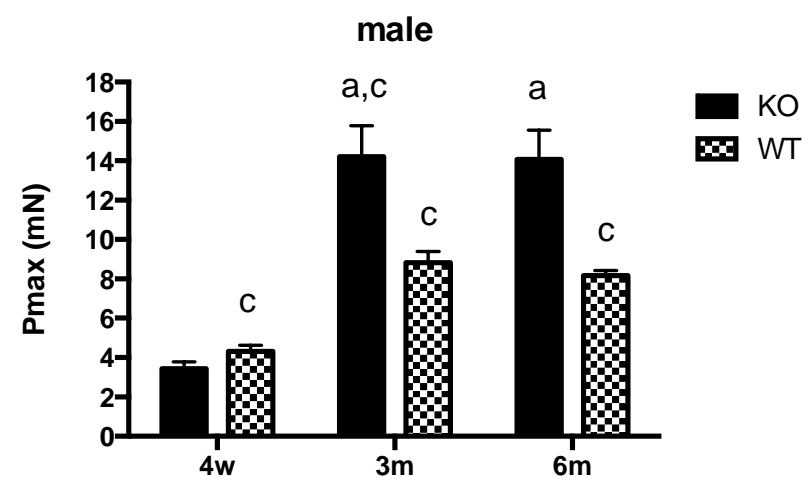

B

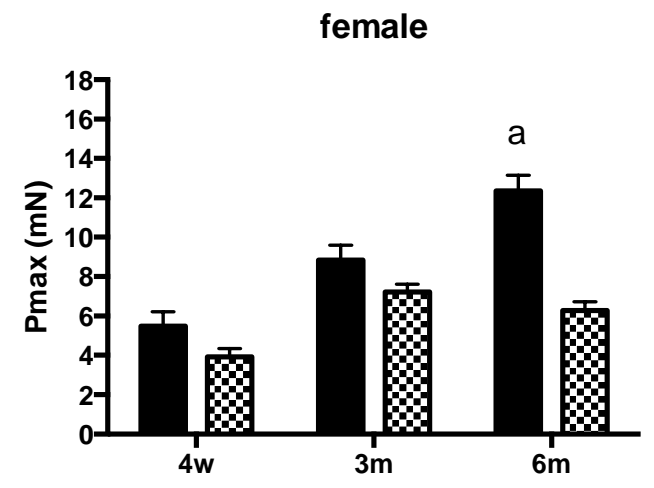

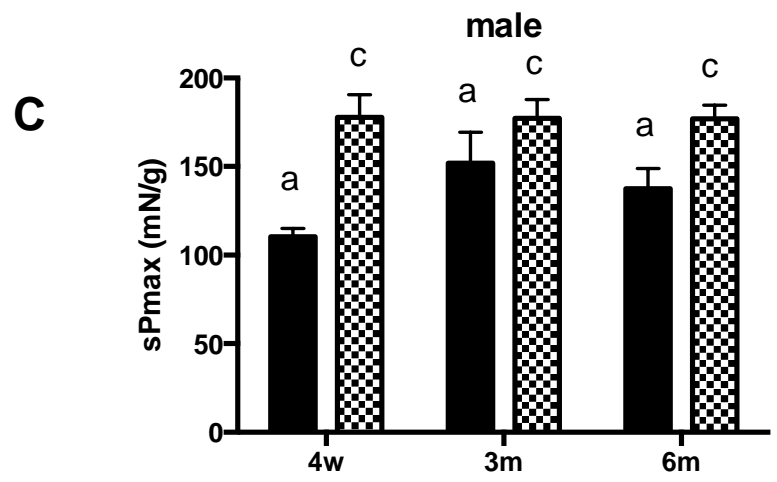

KO

E. WT

E WT

female

D

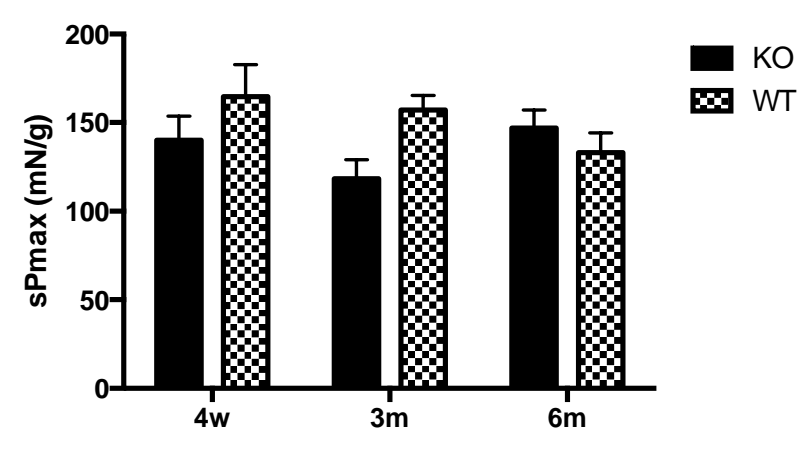


Figure 3

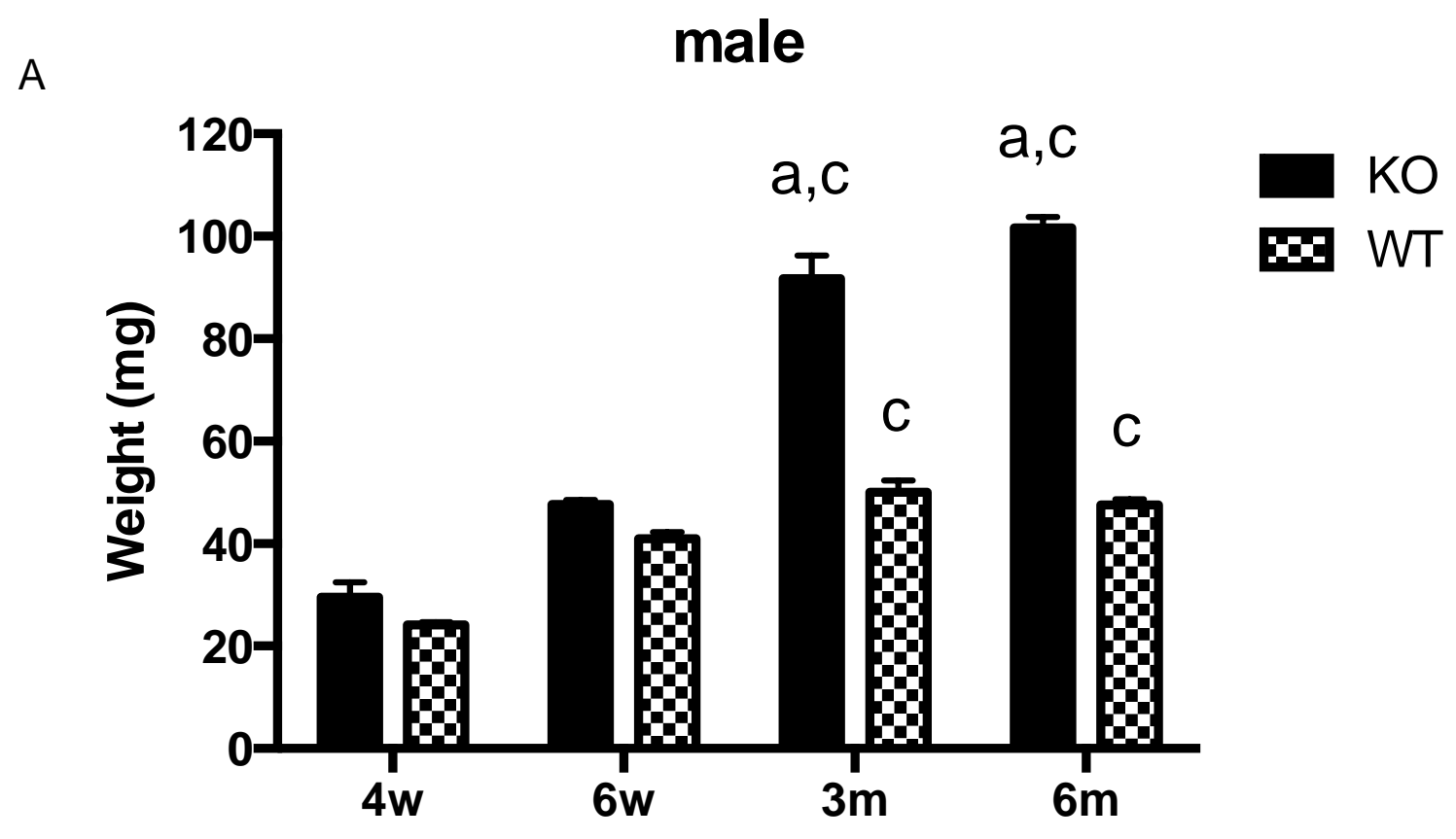

B

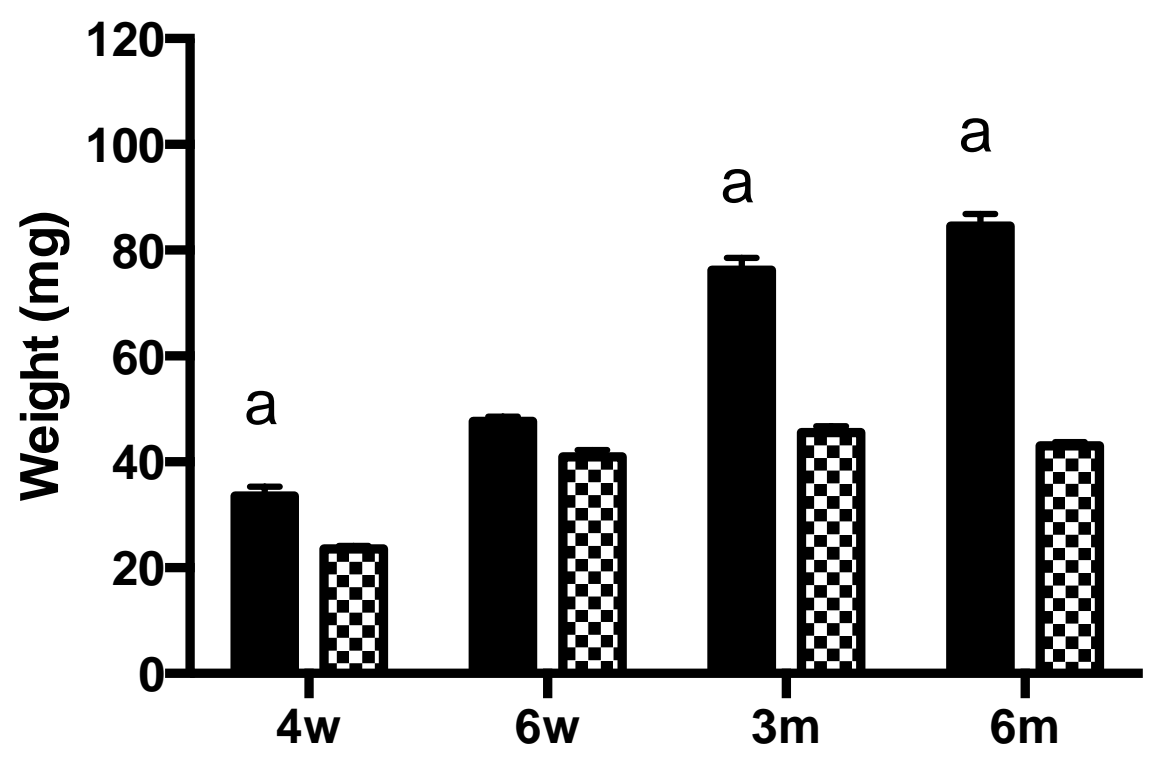


Figure 4

A

male

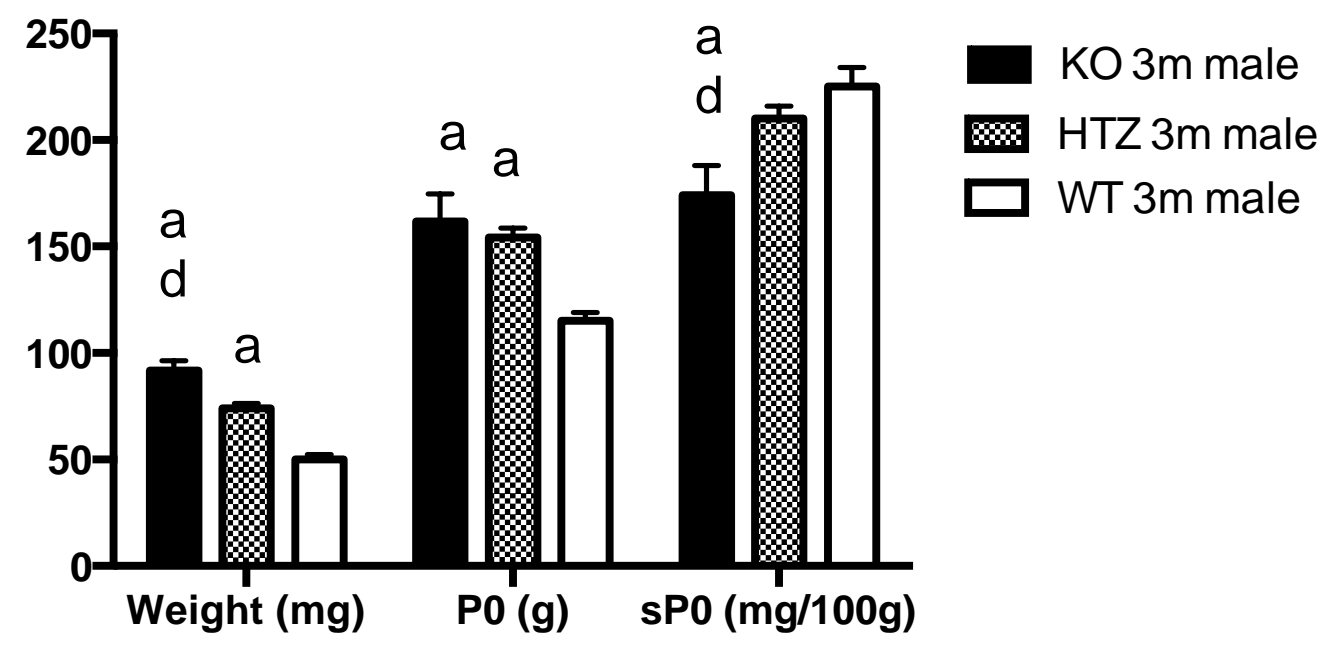

female

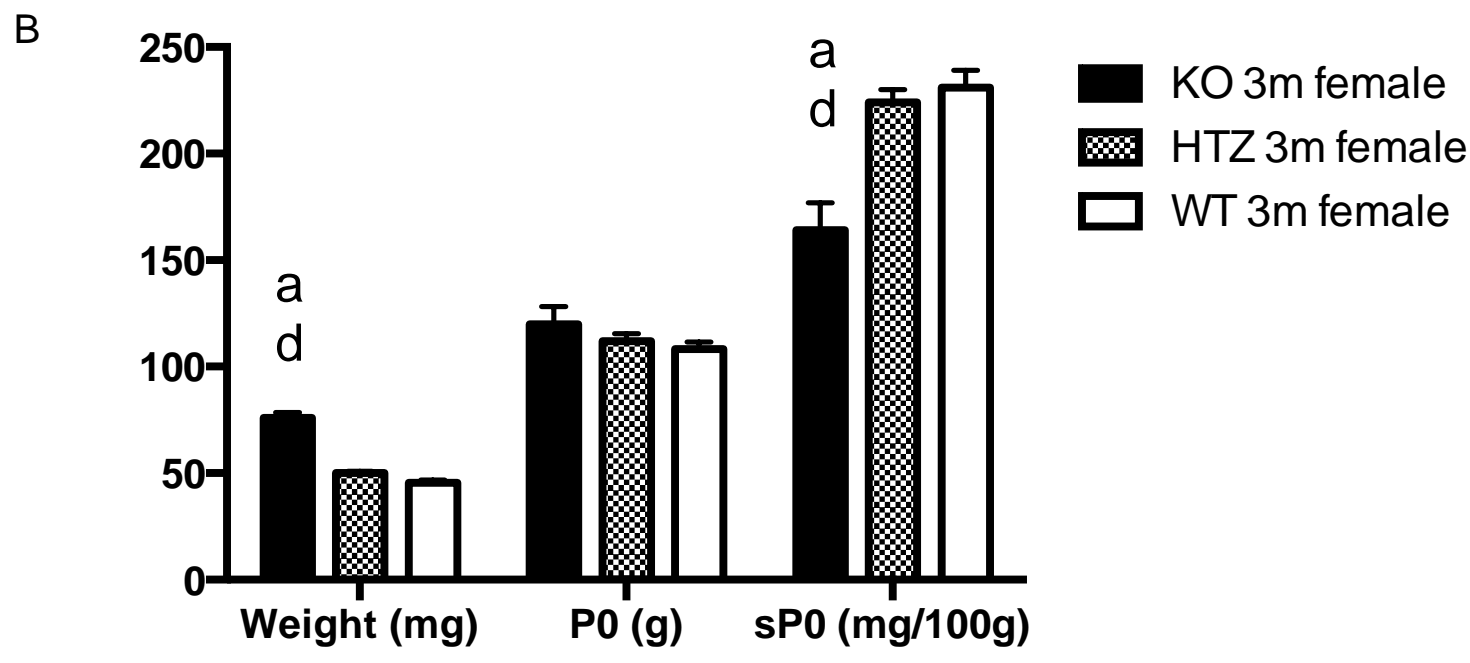




\section{Figure 5}

A

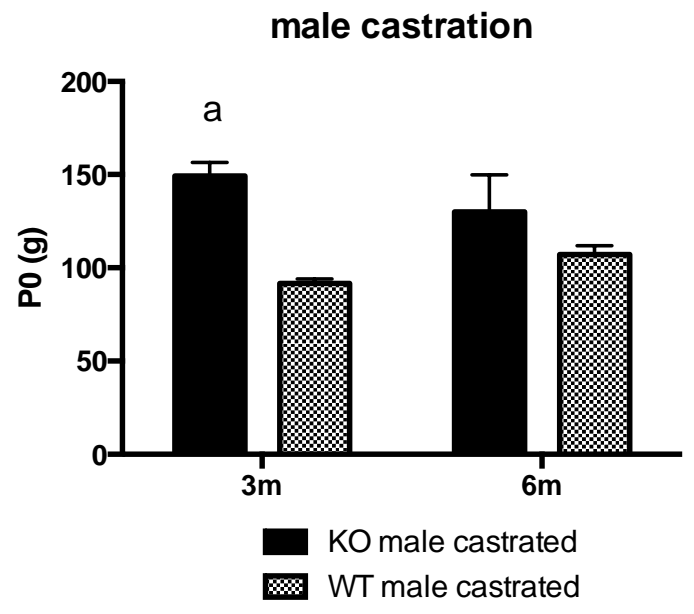

C

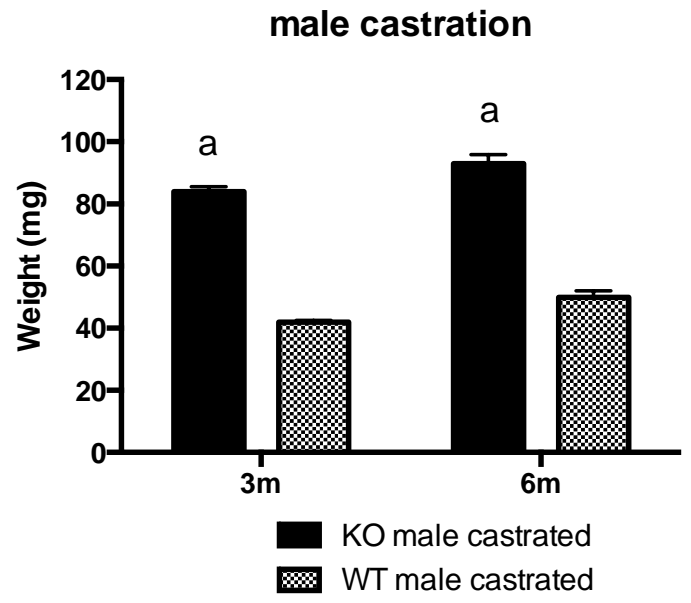

E



B

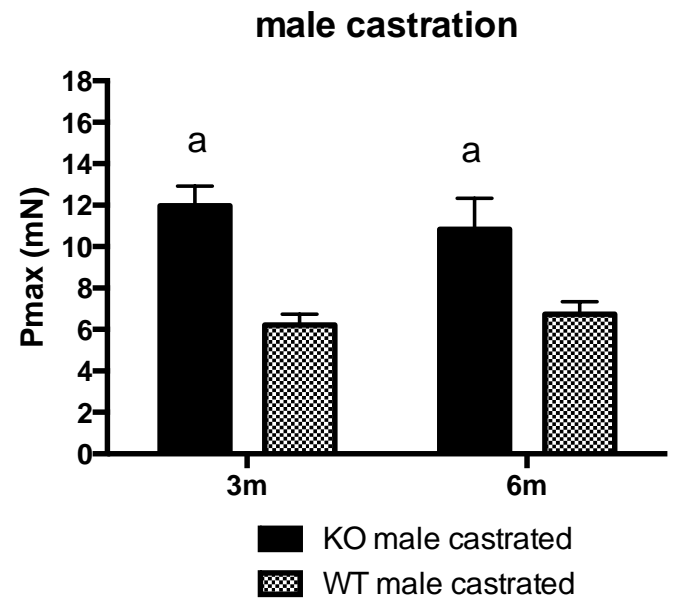

D

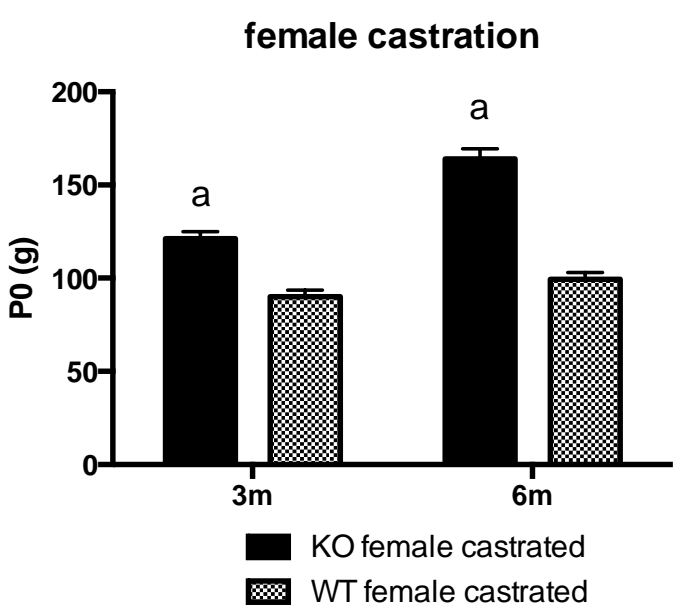

F

female castration

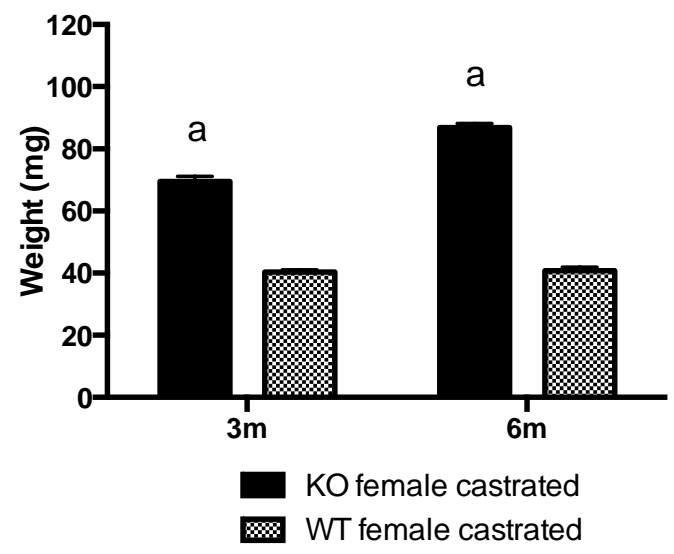


Figure 6

A

Grobet

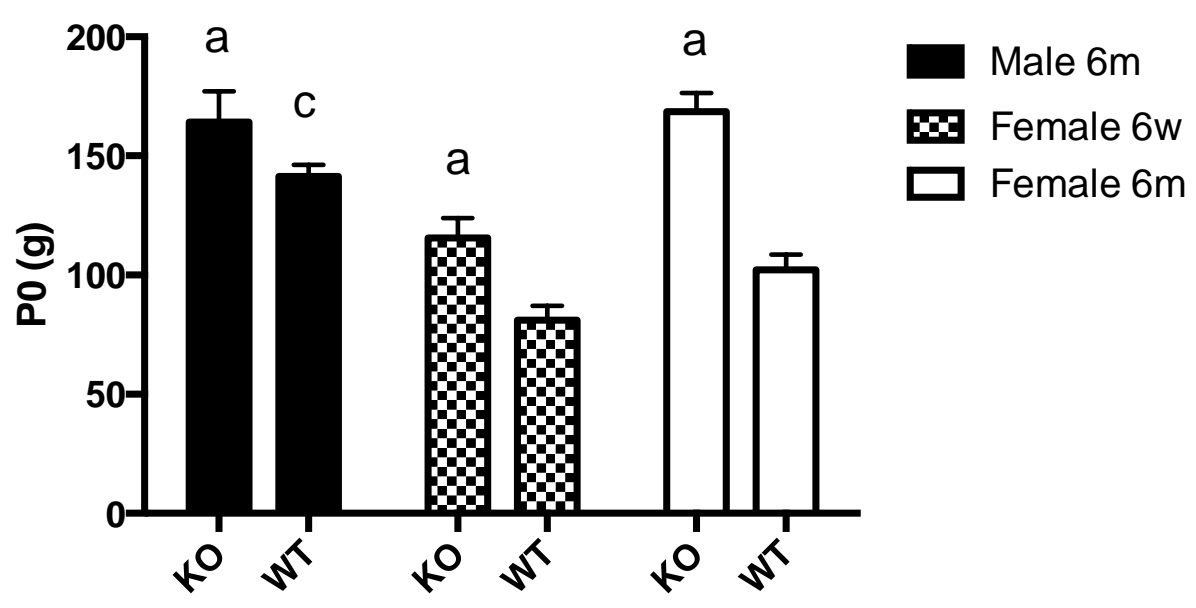

B

Grobet

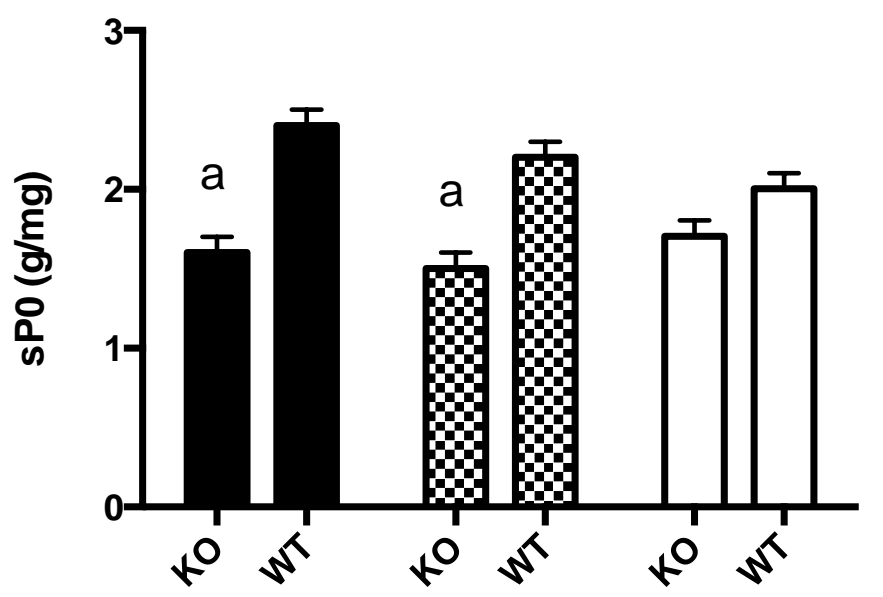

- Male $6 \mathrm{~m}$

E0 Female $6 \mathrm{w}$

$\square$ Female 6m

C

Grobet

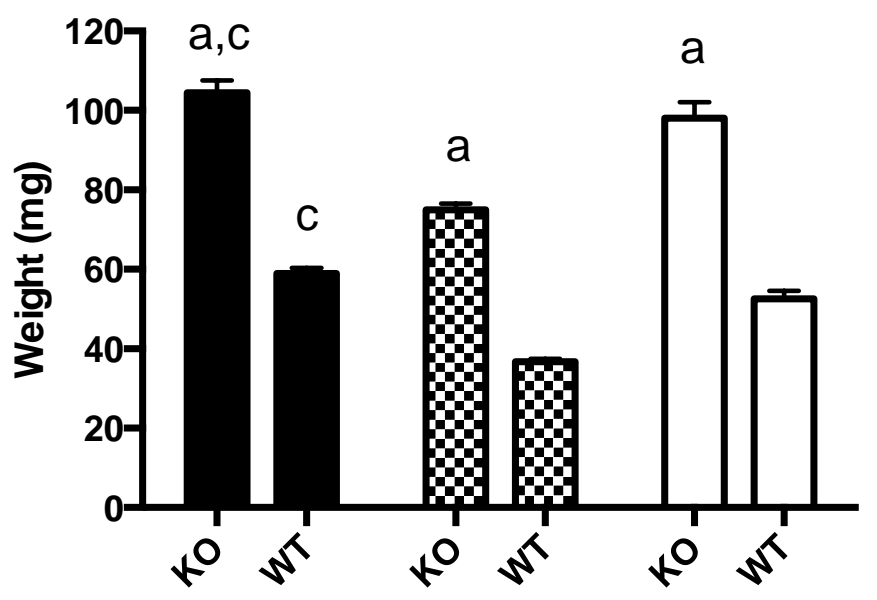
Male $6 \mathrm{~m}$
E Female 6w
$\square$ Female 6m


